\title{
Edebiyat Eğitiminde Unutulmuş Kadın Yazarlar
}

\author{
Ferah Burgul Adıgüzel ${ }^{1}$ \\ "Dünyada ilk kadın okumayı ögrendiğinde \\ kadın problemi ortaya çıktı." \\ Marie von Ebner Eschenbach
}

\begin{abstract}
$\ddot{O} z$
Çalışmanın amacı, kadın yazar ve şairlerin edebiyat eğitimi sürecinde ne düzeyde yer aldıklarını irdeleyerek ögretmen adaylarının kadın yazarlara ilişkin farkındalıklarını belirlemektedir. Bir durumu olabildiğince dikkatli tanımlamayı amaçlayan bu çalışma, var olan bir durumu var olduğu şekilde betimlemeyi amaçlayan tarama modelinde, betimsel bir çalışmadır. Tarama araştırmalarının amacı, genellikle araştırma konusu ile ilgili var olan durumun fotoğrafinı çekerek bir betimleme yapmaktır. Araştırma kapsamında edebiyat eğitiminde kadın yazarların yeri olgusunun tanımlanması amaçlanmış olup çalışma üç aşamada gerçekleştirilmiştir. Çalışmanın ilk aşamasında, edebiyat öğretmen adayları için yarı yapılandırılmış bir görüşme formu hazırlanarak ögretmen adaylarının kadın yazarlara iliş̧kin farkındalıkları belirlenmiştir. Çalışmanın ikinci aşamasında ise orta ögretim edebiyat eğitimi sürecinin bileşenleri olan Türk Edebiyatı ders kitapları ve yüksek öğretim edebiyat eğitimi sürecinde alınan ders içerikleri, ele alınan kadın yazar ve şairler açısından incelenmiştir. Çalışmanın katıllımcılarını bir devlet üniversitesinin Türk Dili ve Edebiyatı Ĕ̆itimi Ana Bilim Dalı'nda öğrenim gören 86 ögretmen adayı oluşturmaktadır. Çalışma kapsamında incelenen dokümanlar; MEB tarafindan basılan Türk Edebiyatı 9, 10, 11 ve 12 sinı ders kitaplart ile ilgili üniversitenin Türk Dili ve Edebiyatı Eğitimi ABD ders içerikleridir. Çalışma kapsamında ulaşılan verilerin analizinde frekans analizi ve betimsel analiz kullanılmıştır. Çalışmanın sonucunda edebiyat öğretmen adaylarının kadın yazar/şairlere ilişkin farkındalıklarının az olduğu, orta öğretim ders kitaplarında ele alınan kadın yazar/şair sayısı ile yüksek ögrrenim sürecinde derslerde ele alınan kadın yazar/şair sayısının yetersiz olduğu belirlenmişstir. Öğretmen adaylarının kadın yazar/şairlere ilişkin farkındalıklarının gelişmemesinde, orta ve yüksek öğretim sürecinde ele alınan kadın şair/yazarlara ait metin saylsındaki yetersizliğin etkili olabileceği düşünülmektedir.
\end{abstract}

Anahtar Sözcükler: Edebiyat eğitimi, Kadın yazar/şairler, Edebiyat ders kitaplarl, Türk dili ve edebiyatı ögretmen adayl

\section{Forgotten Authors in Literature Education}

\begin{abstract}
The objective of this study is to determine the awareness of teacher candidates of female authors by examining to what extent female authors and poets take place in literature education. This study, which aims to define a situation as carefully as possible, is a descriptive study in the review method that aims to describe an existing situation as it is. The objective of survey studies is to take a photo of the existing situation about the subject of research and make a description. It was aimed to define the phenomenon of the place of female authors in literature education within the scope of this study, and the study was conducted in three stages. At the first stage of the study, a semi-structured interview form was prepared for literature teacher candidates and the awareness of teacher candidates of female authors was determined. At the second stage of the study, the content of Turkish literature course books that are the components of secondary literature teaching and higher education literature course books was investigated in terms of female authors and poets. The participants of the study are 86 teacher candidates, who are studying at a state university in Ankara, Department of Turkish Language and Literature. The documents examined within the scope of this
\end{abstract}

1 Dr. Gazi Üniversitesi Gazi Eğitim Fakültesi Türk Dili ve Edebiyatı Eğitimi ABD Öğretim Elemanı. Eposta: fburgul@ gmail.com 
study are Turkish Literature 9, 10, 11 and 12th-grade course books approved by MNE and university Turkish Language and Literature USA course contents. Descriptive analysis was used in the analysis of the data obtained within the scope of this study. As a result of this study, it was found that the awareness of teacher candidates of female authors/poets is low, and the number of female authors/poets addressed in secondary school course books and the number of female authors/poets addressed in lessons during the process of higher education are insufficient. It is believed that the insufficiency of female poets/authors addressed in secondary and higher education process can be effective in the failure of development of the awareness of teacher candidates of female authors/poets.

Keywords: Literature education, Female authors/ poets, Literature course books, Turkish language and literature teacher candidate

\section{Giriș}

Kadının toplumsal yaşamdaki yerinin geçmişi, ilk çağ tarihçilerinden Thukıdies’in "En iyi kadın, kendisinden söz edilmeyen kadındır.” sözüne kadar uzanabilir. Kadının bir sorun haline gelmesi ise Marie von Ebner Eschenbach'ın "Dünyada ilk kadın okumayı öğrendiğinde kadın problemi ortaya çıktı.” sözünde de vurguladığı gibi kadının bilinçli ilk direnişi olan edebiyat/yazı ile karşılaşmasıyla başlar. Edebiyat, yazı, duygu ve düşünceleri ifade etmenin en kalıcı, geçerli ve estetik araçlarından biri, aynı zamanda sosyal olayların, kültürel etkileşimin, duyuş ve düşünüşlerin bir aynasıdır. Bu nedenle kadının edebiyatta yer alması, toplum yaşamında var olması anlamına da geldiği için önem taşımaktadır

Yazma serüveninde, tüm dünya edebiyatlarında olduğu gibi Türk edebiyatında da kadın ve erkek yazarların eş zamanlı olarak ilerlemediği görülmektedir. Türk edebiyatında, kadınların toplum hayatıyla birlikte yazın hayatında da yer alması, Tanzimat ve II. Meşrutiyet ile gelişmeye başlamıştır. Nüfusta sayılarak varlığını resmi olarak bu dönemde (1844) kazanan kadının, veraset hakkını alması (1854) ve üniversite eğitimi izniyle (1914) özgürlük ortamı gelişir ve kadın, mahrem alandan kamusal alana doğru görünürlük kazanır (Karataş, 2009, s.1657). Bu dönemde yayın hayatına başlayan kadın gazete ve dergileri aracılı̆̆ılyla toplumu bilinçlendirmeyi amaçlayan kadınlar, sorun ve beklentilerini yazarak çeşitli basın yayın organları ile dergilerde aktif roller alırlar (Çakır, 1996, s.59; Akt. Çakmak, 2011, s.53). Kendi konumlarını, kimliklerini sorgulamaya, sorunlarını tanımlayıp bunlara ilişkin çözümler sunmaya, haklarını aramaya başlayan bu kadınlar için dönüm noktası; kadınların erkeğin tekelinde olan yazın evrenine girmeleri olmuş ve bu dergiler Osmanlının ilk kadın yazarlarının tanınmasını sağlamıştır (Çakmak, 2011, s.66).

Kadınlar, tarihsel süreç içinde toplumsal haklarını kazandıkları ölçüde, hayatın diğer alanlarında olduğu gibi sanatta da varlıklarını ortaya koyma olanağı bulmuşlardır (Yılmaz, 2012, s.47). Bu nedenle sanatta ve edebiyatta kadının adından daha az söz edilerek, "Neden kadın şair/ yazar sayısı az?" sorusu üzerinden sık sık tartışmalar yapılır. Gerçekten kadın yazar/şair sayısı az mıdır, yoksa bu yazar/şair'ler yeterince tanınmamakta mıdır? Bu sorunun yanıtı edebi dönemler açısından ele alındığında daha açıklayıcı olacaktır.

Halk edebiyatında kadın ozanlar değerlendirildiğinde; sözel kültürün egemen olduğu toplumlarda, edebiyat, özellikle de şiir, toplumsal belleğin hafızasıdır ve sözel kültürün taşıyıcısı genellikle kadınlar olmuştur. Ninni, masal, ağıt gibi halk edebiyatı türlerinin pek çok örneğinin kadınlar tarafından oluşturulduğu ve masal anaları gibi kadın aktarıcılar tarafından yayıldığı görülür. 
Fakat bu konudaki çalışmaların azlığı, aynı zamanda ataerkil bir toplumda hem kadın hem de ozan olarak varlığını sürdürmenin zorluğu nedeniyle kadın halk ozanlarının birçoğu ortaya çıkamamıştır. Özellikle kadın aşıkların ortaya çıkmamasında toplum ve eş baskısı gibi birçok neden söz konusudur. Doğanay (1999) çalışmasında, farklı yüzyıllarda yaşamış toplam 141 kadın halk ozanından bahseder.

15. yüzyıldan itibaren cönklerde Alevi-Bektaşi kadın şairlere rastlamak da mümkündür (Alkaç, 2013): 15. yüzyılda Hafiz Hatun, Leylâ Hatun; 16. yüzyılda Lima Hatun, Havva Hatun, Durriye Hatun; 17. yüzyılda Sakine Hatun, Latife Hanım; 18. yüzyılda Sakine Hatun, Leyla Hatun, Kaduncuk Hatun, Meryem Hatun; 19. yüzyılda Şah Sultan, Nazmiye Hatun, Şerif Bacı, Nehri Bacı, Hayriye Bacı, Afife Bacı, Havva Ana ve diğerleri bunlardan bazılarıdır.

Klasik Türk şiiri incelendiğinde, kadın divan şairlerinin sayılarının çeşitli araştırmacılara göre farklılık gösterdiği görülmektedir. İspirli (2007)'nin çalışmasında adı bilinen ilk kadın şair Zeynep Hatun'dan (15.yy) Rabia Hatun'a kadar 46 kadın divan şairi belirtilmiş, Alkaç (2011)'ın çalışmasında ise ilk tezkireden son tezkireye kadar Osmanlı'da 33 kadın şair yer aldığı ifade edilmiştir. Bekiroğlu (1999) ise sayı belirlemede yapılan çalışmaların yetersiz olduğunu belirterek kadın şairlerin dağılımını farklı bir sınıflandırma ile aktarmaktadır. Divan edebiyatı ve onun Tanzimat yılları arasındaki uzantısını Geleneksel Dönem; Tanzimat sonrası yenilikler ile biçimlenen ve harf inkılâbına (1928) uzanan bölümü ise Yenileşme Dönemi olarak adlandırır. Söz konusu sınıflandırma doğrultusunda; Zeynep Hatun, Mihrî Hatun, Hubbî Hatun, Sitkî Hatun, Ani Hatun, Fitnat Hanım, Leylâ Hanım, Şeref Hanım, Sırrî Hanım, Âdile Sultan, Nakıye Hanım, Münire Hanım, Feride Hanım, Saniye Hanım, Fıtnat Hanım, Leylâ Hanım (Saz), Mahşah Hanım, Hatice İffet Hanım, Hasibe Maide Hanım, Feride Hanım, Habibe Hanım, Şerife Ziba Hanım, Fatma Kâmile gibi şairler de XIX. asır içinde Divan geleneğini sürdürerek şiir yazmışlardır.

Geçmişi altı yüzyıllık bir kültüre dayanan bu edebiyatın kadın şair sayısının azlığı, eğitim alamayan kadınların bu erkek ağırlıklı kültüre girmelerinin ve bu mecliste kabul görebilmelerinin zor olmasında yatar. Ayrıca kadının mahremiyetinin yok sayılması, yerleşmiş gelenek ve görenekleri ile tutucu erkek baskısı da kadın şair sayısının az olmasının gerekçelerindendir. Pala (2008) bu durumu şöyle açıklar:

"Kadının, adının dahi gizli tutulduğu mahremiyet çizgisinin içinde bir kadın şairin sözleriyle, bunlar sanat eseri misralar olsa bile meclislerde sohbet konusu olması kocasınin ya da ailesinin boynunu yere eğen bir kabahat telakki olunur. Şair olmuş yahut olmamış hiç fark etmez. Nitekim o talihsizlerin pek çoğu da sırf erkekler gibi şiir söyledikleri yahut isimleri şuh meclislerde sıkça anıldiğg için ya hiç evlenememiş, ya dul kalmış yahut birkaç koca değiştirmek bahtsızlığını yaşamışlar, velhasıl mesut olamamışlardır."

Tanzimat döneminde, hukuk ve eğitim alanlarında kadınlar lehine bazı gelişmeler yaşanmasıyla kadın yazar sayısında artış görülür. Bu dönemin önemli şair ve yazarları; Zafer Hanım, Fatma Aliye Hanım, Fitnat Hanım, Leylâ Saz Hanım, Nigar Hanım'dır (Aydıngör, 2006, s.85). Söz konusu yazar ve şairlerin yanı sıra Makbule Leman Hanım, Emine Semiye Hanım, Abdülhak Mihrünnisa Hanım, Selma Rıza da sayılabilir (Berkiroğlu, 1999; Aytaç 2007, s.394).

Meşrutiyet dönemi aydını, İslâmcılık, Türkçülük, Batıcılık, Osmanlıcılık başta olmak üzere dönemin belli başı ı fikir akımları programlarında mutlaka "kadın" meselesine yer vererek çözümün eğitimle gerçekleşebileceğinde hemfikir olur. Böylelikle kadının eğitim seviyesinde önceki yıllara oranla bir iyileşme görülür ve kadın mecmuaların ve eli kalem tutan kadın sayısında bir artış fark edilerek basın hayatında ve toplumsal yaşamda kadının varlığı da hissedilmeye başlanmıştır. 
Bu dönemin önemli kadın yazarları İhsan Raif (1877-1926), Yaşar Nezihe (1880-1935) ve Şükûfe Nihal (1896-1973)'dir.

Cumhuriyet dönemi, kadının tüm hukuki haklarını kazandığ ve eğitim açısından en geliştiği dönemdir. Bu dönemde kadın yazar ve şairlerin sayıca bütün dönemlere göre daha fazla olduğu ve artığ1 görülür. Bu durum, kadının toplumda var olabilme oranı ile kadın şair ve yazar sayılarının artması arasında anlamlı bir ilişki olduğunu göstermektedir. Bu dönem kadın yazar ve şairleri 19231990 yılları arası temel alınarak şu şekilde kısaca özetlenebilir: Cumhuriyet'in ilk yılları; Halide Edib Adıvar, Halide Nusret Zorlutuna, Şükufe Nihal, Güzide Sabri Aygün, Müfide Ferit Tek; 193040 arası y1llar Kerime Nadir ile Mükerrem Kamil Su İsmet Kür, İnci Asena, Nezihe Araz; 1960'l1 yıllar Nezihe Meriç, Emine Işınsu, Peride Celal; 1970’li yıllar Adalet Ağaoğlu, Sevgi Soysal, Güney Dal, Pınar Kür, Gülten Akın, Demir Özlü, Aysel Özakın, Afet Ilgaz, Füruzan, Gülseli İnal, Ülker Akçakoca, Türkan İldeniz, Meral Üner, Ayla Ora; 1980'li yıllar Latife Tekin, Ayla Kutlu, Buket Uzuner, Erendüz Atasü, Nazlı Eray, Tezel Özlü, Perihan Mağden, Nilgün Marmara, Lale Müldür, Birhan Keskin; 1990’lı yıllar İnci Aral, Oya Baydar, Ayşe Kulin, Aslı Erdoğan'dır (Yılmaz, 2012, s.55-58; Önertoy, 1998)

Edebi dönemlere dağılımları açısından kısaca değerlendirilen kadın yaar/şair oranları göstermektedir ki Tanzimat döneminden itibaren kadın yazar ve şair sayısı gün geçtikçe artmıştır ama günümüze kadar oluşan edebi akımlar içinde kadın yazar ve şair adı yer alamamıştır. Servet-i Fünun, Fecr-i Âti, Beş Hececiler, Toplumcu Gerçekçiler, Yedi Meşaleciler, Garip dönemleri şairleri arasında kadın şaire rastlanmamaktadır. Bu durumun nedeni, edebi akımların birleştiği edebi grupların aynı zamanda bir sosyal muhit olması (Yılmaz, 2012) ve kadınların bu sosyal muhitlere girmesinin dönemin sosyal koşulları içerisinde kolay olmaması olarak gösterilebilir.

Her ne kadar Cumhuriyet dönemine kadar sayısı artsa da yazın hayatına katılması erkekler kadar eskiye dayanmayan kadınların edebiyat alanında benimsenmesi ve takdir görmesi de erkekler kadar yoğun olmamıştır. Örneğin dinamiti icat ettiği için kendini insanlığa karş1 "suçlu" hisseden kimyager Alfred Nobel tarafından 1895 yllından itibaren verilen Nobel ödülleri incelendiğinde; 2013'e kadar farklı dallardaki Nobel ödüllerini toplam 803 erkek, 44 kadın ve 22 örgütün kazandığ1 görülür. Nobel ödüllerinin tarihinde 15 kadın barış ödülü kazanır, 13'ü edebiyat ödülü kazanır, 10'u fizyoloji ve tıp ödülü alır, 4'ü kimya ödülü alır, 2'si fizik ödülü alır, 1'i de ekonomi nobelini kazanır. İstatistiki olarak değerlendirilirse nobel ödüllü kadınlar, toplam Nobel ödülü alanların sadece \% 5'ini oluşturur ve alanların çoğunluğu da barış ve edebiyat alanında ödül almıştır (Tekeli, 2014).

Edebiyat ödülleri incelendiğinde, Türk yazın hayatında da kadın yazarların kabul ve takdir görmesi sorununun Nobel ödüllerinden pek farklılık göstermediği görülmektedir. Sait Faik, Orhan Kemal, Haldun Taner ve Yunus Nadi ödülleri verilmeye başlandıkları günden bu yıla kadar kadınlara verdikleri ödüller açısından incelendiğinde yine erkekler lehine bir sonuçla karşılaşılmaktadır. 
Tablo 1. Türkiye Edebiyat Ödüllerinde Kadın Yazar ve Şairler

\begin{tabular}{lll}
\hline 1972- ... Orhan Kemal Roman Ödülü & 7 kadın yazar & 53 erkek yazar \\
\hline 1955 - ... Sait Faik Hikaye Armağanı - & 16 kadın yazar & 33 erkek yazar \\
1987- ... Haldun Taner Öykü Ödülü - & 7 kadın yazar & 21 erkek yazar \\
1946- ...Yunus Nadi Ödülleri Roman: & \\
Öykü: & 6 kadın yazar & 22 erkek yazar \\
Şiir: & 13 kadın & 15 erkek \\
& 4 kadın & 33 erkek
\end{tabular}

MEB tarafindan ilk ve orta öğretim sürecinde okunması önerilen iki ayrı 100 Temel Eser listesinde yer alan kitaplar, kadın ve erkek yazar/şairlere yer vermesi açısından incelendiğinde de ortaya kadın yazar/şairin azınlıkta yer aldığı bir liste çıkmaktadır. İlk ve orta öğretim 100 Temel Eser listelerinde yer alan kadın yazar/şairler ve eserlerinin adları şu şekildedir:

Tablo 2. 100 Temel Eserde Kadın Yazarlar

\begin{tabular}{ll}
\hline Ortaöğretim & \\
-Sinekli Bakkal / Mor Salkımlı Ev & Halide Edib Adıvar \\
-İbrahim Efendi Konağı & Samiha Ayverdi \\
İlköğretim & \\
Domaniç Dağlarının Yolcusu & (Şükûfe Nihal) \\
Benim Küçük Dostlarım & (Halide Nusret Zorlutuna) \\
Pollyanna & (Eleanor Porter) \\
Heidi & (Johanna Spyri) \\
Şamatalı Köy & (Astrid Lindgren) \\
Ölümsüz Aile & (Natalie Babbitt) \\
\hline
\end{tabular}

Tablo 2'de görüldüğü üzere 100 Temel Eser listesinde yer alan kadın yazar/şair sayısı yetersizdir. Ancak ilköğretimde kadın yazar sayınının ortaöğretime oranla fazla olması, kadın yazar/ şairlere ayrılan yerin artması açısından daha olumlu görülmekle birlikte yine de yeterli olduğu düşünülmemektedir.

Toplu olarak yazar ya da eser seçkisi sunarak bilgiye ulaşımı kolaylaştırma amacı taşıan antolojiler ve edebiyat tarihi kitapları üzerinde yapılan incelemeler de bu tür kitaplarda kadın yazar ve şairlere yeterince yer verilmediğini göstermektedir. Klasik Türk edebiyatındaki tezkirelerden günümüze aynı anlayışın devam ediyor olması, kadın yazar/şair sayısında görülen artışın zihniyete yeterince yansımadığını göstermektedir. Bu bakış açısı Abdülbaki Gölpınarlı'nın, Mihrî Hanım'1 eserine alma sebebi olarak “... adı tezkirelerde geçtiği, Necâti'yi taklit ettiği ve nihayet bir kadın şair olduğu için aldık.” (Gölpınarlı, 1954, s.18, Akt. İspirli, 2007, s.447) bakışıyla aynı noktadadır.

Edebiyatın sosyal gerçekliği gösteren bir belge olarak da kullanılabileceği (Wellek ve Warren, 2005, s.82) düşünüldüğünde, birçok alanda kadın yazar ve şairlere yer verilme sıklığının azlığı, toplumsal kültürümüzün kadın yazar ve şaire bakış açısının ana çizgilerini oldukça fersiz bir şekilde çizdiğini göstermektedir. 
Kadın yazar ya da şairlerin edebiyat kitaplarında, edebiyat ödüllerinde ve okunması önerilen kitaplar arasında yeterince yer almamasının kadın şair/yazarlara ilişkin çeşitli önyargıların oluşmasını desteklediği düşünülmektedir. Çocuklar, kız ve erkek olarak etiketlenmelerinin ardından cinsiyetin kültürel anlamlarını öğrenmeye ve kazanmaya başlarlar. Kültürümüzde toplumsal düzenlemenin her türlüsünde cinsiyetin etkisi ya da cinsiyete göre ortaya çıkmış bir farklılaşmayı görmek olasıdır. Edebiyata ilişkin en sık kullanılan "Kadın şiir yazmaz, kadın için şiir yazılır." ön yargısı da onlardan biridir. Adonis'in sözleriyle "Kadından şair olmaz. Çünkü kadının kendisi şiirdir, şiir yazdı̆̆ı zaman kendini tekrarlamış olur.” ifade edilen bu ön yargı, toplumun kadınları için uygun gördüğü rol ve faaliyetleri gösteren cinsiyet rollerine ilişkin kalıpyargılar arasında yer almaktadır.

Kültürümüzde toplumsal düzenlemenin her türlüsünde cinsiyetin etkisi ya da cinsiyete göre ortaya çıkmış bir farklılaşmayı görmek mümkündür. Kültürel farklılıklar olmakla birlikte, genellikle kadınların ilgi ve bakım verici, pasif gibi özelliklere sahip oldukları, erkeklerin de aktif ve başarılı oldukları düşünülür (Dökmen, 2012, s.32). Kadına ilişkin bu kalıpyargının oluşma sebeplerinden bazıları; kadının uzun süre eğitim hakkını almaması nedeniyle yazıdan uzak kalması, duygularını ifade etmesinin mahrem alanını sergilemek olarak algılanması, eğitim alması ile toplumsal hayata karışsa da iyi bir anne ve iyi bir eş kalıbından çıkmasının istenmemesi olarak sıralanabilir. Bu kalıpyargıların sürdürülmesinde ailenin ve diğer toplum kurumlarının yanı sıra kitle iletişim araçlarının, çocuk kitaplarının, reklamların, filmlerin, kliplerin ve okul ders kitaplarının ciddi rolleri bulunmaktadır.

Çocuklar, kız ve erkek olarak etiketlenmelerinin ardından cinsiyetin kültürel anlamlarını öğrenmeye ve kazanmaya başlarlar. Eğitim, eğitim sistemi ve ders kitaplarının cinsiyet rolleri bağlamında incelenmesi yeni bir neslin düşünce yapısının oluşmasında büyük önem taşır çünkü her devlet, ders kitapları aracılığıyla ideolojisini aktarmaya çalışarak yaratmak istediği yurttaşı biçimlendirmekte ve geleceğe yönelik yatırım yapmaktadır (Zeybekoğlu, 2013, s.46). Bu nedenle ders kitaplarında görülen cinsiyet ayrımcılığı birçok çalışmaya konu olmuştur. Doğan (1994), Ders kitapların ve sosyalleşme adlı çalışmasında 1876-1918 yılları arasındaki döneme ait ders kitaplarında kadınlar aleyhine unsurlara dikkat çekmiştir. Helvacıoğlu (1996)'nun 1928-1995 yılları arasında ilk ve ortaokul ders kitaplarındaki cinsiyetçilik olgusunu incelediği çalışmada Cumhuriyet' in ilk yıllarındaki ders kitaplarında kadın ve erkeğin sürekli yardımlaşma içinde olan kişiler olarak sunulduğu ve kadın işi-erkek işi ayrımının yapılmadığı, kadının kamusal alanda yer alması konusunda cesaretlendirdiği; 1945 sonrası dönemde kadınların asıl görevinin evi ve ailesi olduğu düşüncesini pekiştiren örneklerin işlenmeye başlandığı, 1950'den sonra ise kadının sadece ev içi alanla tanımlanmaya başladığı, halkçı laik ve milli ekonomiyi güçlendirici söylemden uzaklaşılarak dini temaların yoğunlaştığını belirtmektedir. 2008 yılında Tarih Vakfı ve Türkiye İnsan Hakları Vakfı tarafından geçekleştirilen Ders Kitaplarında İnsan Hakları Raporuna göre, ilk ve orta öğretimde okutulmakta olan 139 ders kitabı üzerinde yapılan çalışma kapsamında ders kitaplarının cinsiyet ayrımcılığı ve karşı ayrımcı olduğu, kadına biçilen toplumsal roller açısından sorunludur (DKİH Projesi, 2009).

Edebiyat, toplumun ifadesidir; ancak sadece toplumun yazarı etkilediği düşünülemez, yazar da toplumu etkiler. Sanat hayatı sadece kopya etmez, aynı zamanda onu şekillendirir. İnsanlar roman ve hikâyelerdeki kadın ve erkek kahramanların davranışlarını örnek alabilirler (Wellek ve Warren, 2005, s.81), edebiyat hitap ettiği kitleyi etkiler. Bu nedenle okurun kadın ve erkek yazarlardan kadın ve erkek yaklaşımı ile edebi ürünlerdeki eril ve dişil dilin yansımasını görmesi gerekir. Elbette “Adalet Ağaoğlu'nun, Halide Edib Adıvar'ın ya da Tezer Özlü’nün kadın olup olmadıkları önemli 
değildir, önemli olan başarılı edebiyat ürünlerinin ortaya konmasıdır, ancak kadın yazarlarla birlikte edebiyatımızda kadın duyarlılığının belirgin bir şekilde hissedilmeye başlandığı da yadsınmamalıdır. Kadının bakış açısı, sosyal konumu ve kimliği, edebiyatımızda yeni bir pencere açar ve okur bu yeni pencereden de manzarayı izleyebilmelidir.

Kadına biçilen toplumsal rollerin oluşturulmasında olduğu gibi kadın yazarlara ilişkin kalıpyargıların aşılmasında kullanılabilecek en önemli araçlar da ders kitaplarıdır. Eğitim sürecinde kadın yazar ya da şairin yapıtıyla karşılaşmayan bir öğrencinin kadın yazar/şaire ilişkin farkındalığının gelişmesi ve "kadın şiir yazmaz, yazdırır" şeklindeki kalıp yargıları kırması beklenemez. Dolayısıyla sayıları az olarak belirtilen kadın yazar ve şairlerin aslında az olmadığı bilinmekte, ancak edebiyat eğitimi sürecinde öğrencilere yeterince aktarılmadığı düşünülmektedir. Kadın yazar ve şairlere ilişkin ön yargıların azalması ve onlara ilişkin farkındalı̆̆ın artmasında ders kitapları gibi birincil eğitim araçlarının ders kitaplarında kadın ve erkek yazarların oranı açısından toplumsal cinsiyetçi yapıdan uzaklaşması gerektiği düşünülmektedir.

\section{Çalışmanın Amacı}

Çalışmanın amacı, kadın yazar ve şairlerin edebiyat eğitimi sürecinde ne düzeyde yer aldıklarını irdeleyerek Türk dili ve edebiyatı öğretmen adaylarının kadın yazarlara ilişkin farkındalıklarını belirlemektedir.

\section{Yöntem}

$\mathrm{Bu}$ çalışma, var olan bir durumu var olduğu şekilde betimlemeyi amaçlayan tarama modelinde bir çalışmadır. Tarama araştırmalarında, geçmiş olaylara ilişkin olgu bulma, ilişki kurma ve yargılarda bulunabilme amacı ile kanıtların toplandırılması ve değerlendirilmesi önem kazanır (Karasar, 2002, s.78). Tarama araştırmalarının amacı genellikle araştırma konusu ile ilgili var olan durumun fotoğrafını çekerek bir betimleme yapmaktır. Betimsel araştırmanın tarama modelindeki bu çalışma ile bir konuya ya da olaya ilişkin katılımcıların görüşlerinin ya da ilgi, beceri, yetenek, tutum gibi özelliklerinin belirlendiği araştırmalardır (Büyüköztürk vd., 2010, s.231). Araştırma kapsamında edebiyat eğitiminde kadın yazarların yeri olgusunun tanımlanması amaçlanmış olup çalışma üç aşamada gerçekleştirilmiştir. Çalışmanın ilk aşamasında, Türk dili ve edebiyatı öğretmen adayları için yarı yapılandırılmış bir görüşme formu hazırlanarak öğretmen adaylarının kadın yazarlara ilişkin farkındalıkları belirlenmiştir. Çalışmanın ikinci aşamasında ise orta öğretim edebiyat eğitimi sürecinin bileşenleri olan Türk Edebiyatı ders kitapları ve yüksek öğretim edebiyat eğitimi sürecinde alınan ders içerikleri ele alınan kadın yazar ve şairler açısından incelenmiştir. Öğretmen adaylarının kadın yazar/şairlere ilişkin farkındalıkları ile aldıkları eğitim sürecinde gördükleri kadın yazar/şairler karşılaştırılmıştır.

\section{Araştırmanın Katılımcıları}

Araştırmanın katılımcılarını, 2013 güz eğitim öğretim döneminde bir devlet üniversitesinin Türk Dili ve Edebiyatı Öğretmenliği ana bilim dalında öğrenim gören öğrencilerinden toplam 86 öğretmen adayı oluşturmaktadır. Öğrencilerin 56’sı kadın ve 30’u erkek olup yaşları 22 ile 26 arasında değişmektedir. 


\section{Veri Toplama Araçları}

Çalışma kapsamında incelenen dokümanlar; Türk edebiyatı öğretmen adaylarının kadın yazarlara ilişkin farkındalıklarını belirlemeyi amaçlayan açık uçlu sorulardan oluşan soru kağıdı, Türk Dili ve Edebiyatı Eğitimi ana bilim dalı ders içerikleri, 9, 10, 11, 12 sınıf Türk Edebiyatı (MEB) ders kitapları oluşturmaktadır.

\section{İşlem Basamakları}

Çalışmada doğrultusundaki verilere ulaşmada izlenen yol işlem basamakları şeklinde şematik olarak aşağıda gösterilmiştir.

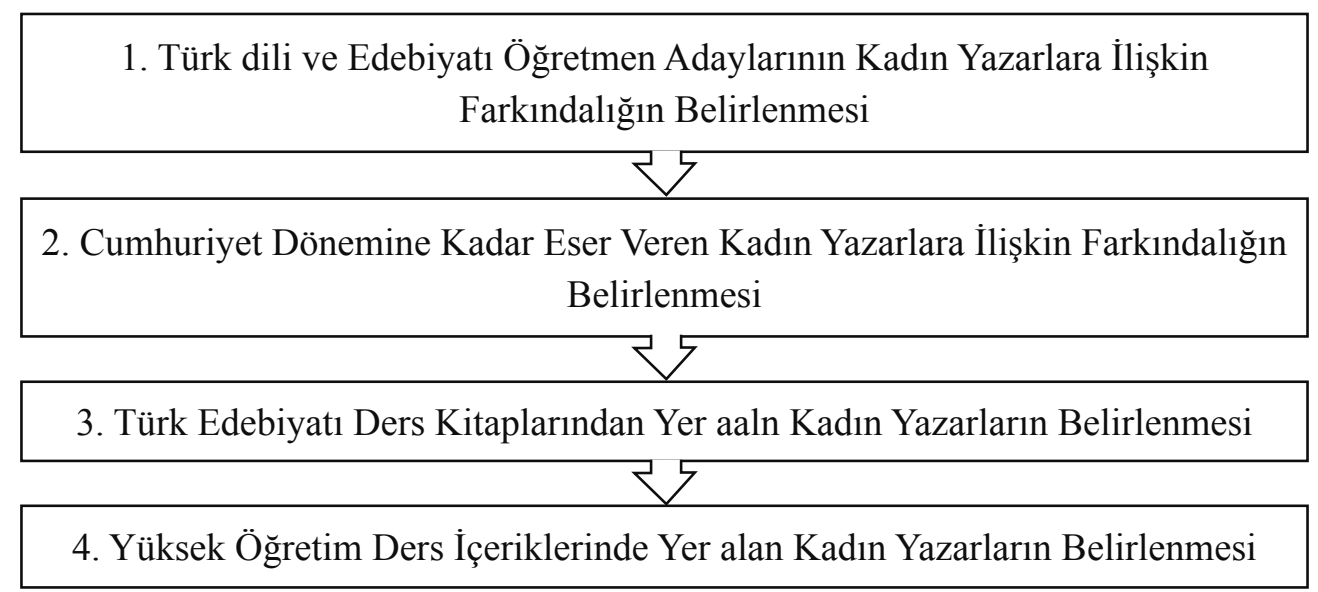

\section{Verilerin Analizi}

Doküman incelemesi ile toplanan verilerin analizinde frekans analizi ve betimsel analizden yararlanılmıştır. Doküman analizi, araştırılması hedeflenen olgu veya olgular hakkında bilgi içeren materyallerin analizini kapsar (Yıldırım, 2011, s.187). Bu doğrultuda ders kitapları ve öğretmen adayları tarafından soru kağıtlarına verilen cevaplar; kitaplarda kadın yazar/şairlerin yer alma sıklıkları ve kadın yazarlara ilişkin farkındalık açısından incelenmiştir.

\section{Bulgular ve Yorum}

Türk Dili ve Edebiyatı Öğretmen Adaylarının Okuduğu Kadın Yazarlara İlişkin Bulgular

Çalışma kapsamında edebiyat öğretmen adaylarına okumaktan hoşlandıkları yazar ve şairler sorulmuştur. Öğrenciler toplam 167 yazar/şair adı söylemiş ve bu isimlerden 112'sinin erkek, 15'inin kadın olduğu belirlenmiştir. Öğretmen adaylarından on ve daha fazla kişinin okumaktan hoşlandığ yazar/şair isimleri Tablo 3’te gösterilmiştir. 
Tablo 3. Türk Dili ve Edebiyatı Öğretmen Adaylarının Okuduğu Yazarların Sıklık Durumu

\begin{tabular}{|c|c|c|c|}
\hline & Yazar Adı & $\mathbf{f}$ & $\%$ \\
\hline 1 & İskender Pala & 41 & 47,6 \\
\hline 2 & Necip Fazıl Kısakürek & 40 & 46,5 \\
\hline 3 & Ahmet Hamdi Tanpınar & 30 & 34,8 \\
\hline 4 & Nazım Hikmet Ran & 26 & 30,2 \\
\hline 5 & Yahya Kemal Beyatlı & 25 & 29,0 \\
\hline 6 & Cemal Süreya & 24 & 27,9 \\
\hline 7 & Peyami Safa & 23 & 26,7 \\
\hline 8 & Attila İlhan & 21 & 24,4 \\
\hline 9 & ELİF ŞAFAK & 21 & 24,4 \\
\hline 10 & Mehmet Akif Ersoy & 20 & 23,2 \\
\hline 11 & Halit Ziya Uşaklıgil & 19 & 22,0 \\
\hline 12 & Orhan Veli & 19 & 22,0 \\
\hline 13 & Reşat Nuri Güntekin & 18 & 20,9 \\
\hline 14 & Özdemir Asaf & 17 & 19,7 \\
\hline 15 & Namık Kemal & 15 & 17,4 \\
\hline 16 & NAZAN BEKİROĞLU & 15 & 17,4 \\
\hline 17 & Can Yücel & 14 & 16,2 \\
\hline 18 & Ümit Yaşar Oğuzcan & 14 & 16,2 \\
\hline 19 & Ahmet Ümit & 12 & 13,9 \\
\hline 20 & Cengiz Aytmatov & 12 & 13,9 \\
\hline 21 & EMINE IŞINSU & 12 & 13,9 \\
\hline 22 & Hüseyin Nihal Atsız & 12 & 13,9 \\
\hline 23 & Oğuz Atay & 12 & 13,9 \\
\hline 24 & Tarık Buğra & 12 & 13,9 \\
\hline 25 & Yaşar Kemal & 12 & 13,9 \\
\hline 26 & Sabahattin Ali & 11 & 12,7 \\
\hline 27 & Sezai Karakoç & 11 & 12,7 \\
\hline 28 & Cahit Sitk1 Taranc1 & 10 & 11,6 \\
\hline 29 & Yavuz Bülent Bakiler & 10 & 11,6 \\
\hline
\end{tabular}

Seksen altı öğretmen adayına okumaktan hoşlandıkları yazarlar sorularak adı on ve daha fazla kişi tarafindan söylenen yazarlar Tablo 3'te gösterilmiştir. Tablo 3'e göre, öğretmen adaylarının en sık okuduğu yazar İskender Pala $(\% 47,6)$, Necip Fazıl Kısakürek $(\% 46,5)$ ve Ahmet Hamdi Tanpınar $(\% 34,8)$ 'dır. Yirmi dokuz yazarın adının bulunduğu bu listede yer alan kadın yazar sayısı üçtür. Bu yazarlar, okunma sıklıklarına göre Elif Şafak $(\% 24,4)$, Nazan Bekiroğlu $(\% 17,4)$ ve Emine Işınsu $(\% 13,9)$ 'dur.

Öğretmen adaylarına okumaktan hoşlandıkları kadın yazarlar sorulmuş ve öğretmen adaylarının okumaktan hoşlandığı kadın yazar/şairlerin adları ve söylenme sıklıkları Tablo 4 'te gösterilmiştir. 
Tablo 4. Türk Dili ve Edebiyatı Öğretmen Adaylarının Okuduğu Kadın Yazarlar

\begin{tabular}{rlrr}
\hline & Yazar Adı & f & $\mathbf{\%}$ \\
\hline $\mathbf{1}$ & Elif Şafak* & 21 & 24,4 \\
\hline $\mathbf{2}$ & Nazan Bekiroğlu & 15 & 17,4 \\
$\mathbf{3}$ & Emine Işınsu* & 12 & 13,9 \\
\hline $\mathbf{4}$ & Samiha Ayverdi & 7 & 8,1 \\
$\mathbf{5}$ & Alev Alatlı* & 6 & 6,9 \\
\hline $\mathbf{6}$ & Ayşe Kulin & 6 & 6,9 \\
$\mathbf{7}$ & Canan Tan & 6 & 6,9 \\
$\mathbf{8}$ & Buket Uzuner & 3 & 3,4 \\
$\mathbf{9}$ & Adalet Ağaoğlu* & 2 & 2,3 \\
$\mathbf{1 0}$ & Sevinç Çokum & 2 & 2,3 \\
$\mathbf{1 1}$ & Halide Edib Adıvar* & 1 & 1,1 \\
$\mathbf{1 2}$ & Mina Urgan & 1 & 1,1 \\
$\mathbf{1 3}$ & Nilgün Marmara & 1 & 1,1 \\
$\mathbf{1 4}$ & Pınar Kür & 1 & 1,1 \\
$\mathbf{1 5}$ & Sevgi Çiçek & 1 & 1,1 \\
\hline
\end{tabular}

Tablo 4'e göre, Elif Şafak, Nazan Bekiroğlu ve Emine Işınsu dışında on iki yazar adı söylenmiştir ve adı söylenen yazarların söylenme sıklığı onun altında olup beş kadın yazar/şair adını sadece bir öğretmen adayı belirtmiştir. Ayrıca öğretmen adaylarının adını belirtmiş oldukları kadın yazarlardan Elif Şafak ve Emine Işınsu, Alev Alatlı, Halide Edib Adıvar ve Adalet Ağaoğlu, lisans eğitimi sürecinde Yeni Türk Edebiyatı dersi kapsamında ödev ya da ders kapsamında işlenmiştir.

Türk Dili ve Edebiyatı Öğretmen Adaylarının Cumhuriyet Dönemi Öncesi Kadın Yazarlara İlişkin Farkındalıklarına Yönelik Bulgular

Çalışma kapsamında edebiyatöğretmen adaylarına "İslamiyet Etkisindeki Türk Edebiyatından Cumhuriyet Dönemine kadar geçen süreci ele alan bir antoloji hazırlamanı gerekirse bu antolojide kimlere yer verirsiniz?" sorusu yöneltilmiş, öğretmen adaylarının yanıtları Tablo 5 'te gösterilmiştir.

Tablo 5. Öğretmen Adaylarının Cumhuriyet Dönemi Öncesi Kadın Yazarlara Illişkin Farkındalıkları

\begin{tabular}{llrr}
\hline & Yazar Adı & f & $\mathbf{\%}$ \\
\hline $\mathbf{1}$ & Namık Kemal & 14 & 16,2 \\
$\mathbf{2}$ & Fuzuli & 13 & 15,1 \\
$\mathbf{3}$ & Baki & 13 & 15,1 \\
$\mathbf{4}$ & Yunus Emre & 12 & 13,9 \\
$\mathbf{5}$ & Nefi & 12 & 13,9 \\
$\mathbf{6}$ & Halit Ziya Uşaklıgil & 12 & 13,9 \\
$\mathbf{7}$ & Nedim & 11 & 12,7 \\
$\mathbf{8}$ & Recaizade Mahmut Ekrem & 11 & 12,7 \\
$\mathbf{9}$ & Tevfik Fikret & 11 & 12,7
\end{tabular}

* Üniversite eğitimi sürecinde ödev ya da ders kapsamında işlenen yazarlar. 


\begin{tabular}{llrr}
$\mathbf{1 0}$ & Ahmet Haşim & 11 & 12,7 \\
$\mathbf{1 1}$ & Ziya Paşa & 10 & 11,6 \\
$\mathbf{1 2}$ & Cenap Şehabettin & 10 & 11,6 \\
$\mathbf{1 3}$ & Ahmet Yesevi & 8 & 9,3 \\
$\mathbf{1 4}$ & Mevlana & 8 & 9,3 \\
$\mathbf{1 5}$ & Ahmet Mithat Efendi & 8 & 9,3 \\
$\mathbf{1 6}$ & Mehmet Rauf & 8 & 9,3 \\
\hline $\mathbf{1 7}$ & HALİDE EDİP ADIVAR* & 8 & 9,3 \\
\hline $\mathbf{1 8}$ & Şeyh Galip & 7 & 8,1 \\
\hline $\mathbf{1 9}$ & Karacaoğlan & 7 & 8,1 \\
\hline $\mathbf{2 0}$ & Şinasi & 7 & 8,1 \\
$\mathbf{2 1}$ & Abdülhak Hamit Tarhan & 7 & 8,1 \\
\hline $\mathbf{2 2}$ & Yakup Kadri Karaosmanoğlu & 7 & 8,1 \\
\hline $\mathbf{2 3}$ & Ziya Gökalp & 7 & 8,1 \\
\hline $\mathbf{2 4}$ & Mehmet Emin Yurdakul & 7 & 8,1 \\
\hline $\mathbf{2 5}$ & Yahya Kemal Beyatlı & 7 & 8,1 \\
\hline $\mathbf{2 6}$ & Mehmet Akif Ersoy & 7 & 8,1 \\
\hline $\mathbf{2 7}$ & Yusuf Has Hacip & 6 & 6,9 \\
\hline $\mathbf{2 8}$ & Kaşgarlı Mahmut & 6 & 6,9 \\
$\mathbf{2 9}$ & Hacı Bektaşi Veli & 6 & 6,9 \\
\hline $\mathbf{3 0}$ & Necati & 6 & 6,9 \\
\hline & & & \\
\hline
\end{tabular}

Öğretmen adayları bu soruyu yanıtlarken 79 farklı yazar/şair adı belirtmişler ve bu yazar adlarından biri bir kadın yazara Halide Edib Adıvar'a (\%9,3) aittir. Bu durum, özellikle Cumhuriyet öncesi dönemde yaşayan kadın yazar/şairlere ilişkin farkındalığın oldukça düşük olduğunu göstermektedir.

Türk Dili ve Edebiyatı Eğitimi Lisans Programı Ders İçeriklerinde Yer Alan Kadın Yazarlara İlişkin Bulgular

Çalışma kapsamında Türk dili ve edebiyatı öğretmenliği lisans programı ders içerikleri yıl ve dersler bağlamında ele alınan kadın yazarlar açısından ele alınmıştır. Öğretmen adayları ile yapılan görüşmeler ve ders içeriklerinde belirtilen içerikler incelendiğinde lisans programında derslere göre işılenen alınan kadın yazar/şairler ve sınıflara göre dağılımları Tablo 6' da gösterilmiştir.

Tablo 6. Türk Dili ve Edebiyatı Eğitimi Lisans Programı Ders İçeriklerinde Yer Alan Kadın Yazar

\begin{tabular}{lll}
\hline Yeni Türk Edebiyatı & Eski Türk Edebiyatı & Halk Edebiyatı \\
\hline 1. Sınıf: Fatma Aliye & 1. Sınıf: Zeynep Hanım, & 1. Sınıf: - \\
2. Sınıf: Halide Edip Adıvar & Mihrî Hanım & 2. Sınıf: - \\
3. Sınıf: - & 2. Sınıf: - & 3. Sınıf: Ayşe Bacı \\
4. Sınıf: Adalet Ağaoğlu, Emine & 3. Sinıf: - & 4. Sınıf: - \\
Işınsu, Alev Alatlı, Elif Şafak & 4. Sınıf: - & 5. Sınıf:- \\
5. Sınıf: & 5. Sınıf:- & \\
\hline
\end{tabular}


Edebiyat öğretmenliği lisans programı ders içerikleri incelendiğinde, yüksek öğretim sürecinde öğretmen adaylarının dokuz kadın şair/yazarın metni ile çalıştıkları ve onlara ilişkin ders işledikleri görülmüştür. Öğrencilerin öğrenim sürecinde işledikleri yazarları sevdikleri yazarlar arasında gösterdikleri dikkat çekmektedir.

\section{MEB Türk Edebiyatı Ders Kitaplarında Yer Alan Kadın Yazarlara İlişkin Bulgular}

Çalışma doğrultusunda MEB tarafindan onaylanan ortaöğretim Türk Edebiyatı 9, 10, 11 ve 12 sınıf ders kitapları kadın yazar/şairlere yer verme sıklığı açısından incelenmiştir. Türk edebiyatı ders kitapları; metin, inceleme, etkinlik, değerlendirme ve okunası tavsiye edilen bölümleri altında incelenerek örnek metninden yararlanılan kadın yazar/şairler Tablo 7'de gösterilmişstir.

Tablo 7. MEB Türk Edebiyatı Ders Kitaplarında Yer Alan Kadın Yazarlara İlişkin Bulgular

\begin{tabular}{|c|c|c|c|c|c|}
\hline Sinif & Okuma Metni & İnceleme & Etkinlik & Değerlendirme & $\begin{array}{l}\text { Okunması } \\
\text { Tavsiye } \\
\text { Edilen Eser }\end{array}$ \\
\hline \multirow[t]{2}{*}{ 9.SINIF } & - & - & $\begin{array}{l}\text { Şükûfe Nihal Başar } \\
(2013, \text { s.30) }\end{array}$ & $\begin{array}{l}\text { Leylâ Hanım } \\
\text { (2013, s.58) } \\
\text { (bir beyit) }\end{array}$ & - \\
\hline & & & $\begin{array}{l}\text { Halide Edib Adıvar } \\
\text { (Sinekli Bakkal } \\
\text { romanından bir paragraf) }\end{array}$ & & \\
\hline $\begin{array}{l}10 . \\
\text { SINIF }\end{array}$ & - & - & - & - & - \\
\hline 11. SINIF & $\begin{array}{l}\text { Halide Edib } \\
\text { Adıvar } \\
\text { (Muharebeyi } \\
\text { Kazananlar) } \\
(2013, \text { s.146- } \\
147)\end{array}$ & $\begin{array}{l}\text { Halide Edib } \\
\text { Adıvar } \\
\text { (Ateşten Göm- } \\
\text { lek) } \\
(2013 \text {, s.185- } \\
188)\end{array}$ & $\begin{array}{l}\text { Sabiha Sertel } \\
(2013, \text { s. } 98)\end{array}$ & - & $\begin{array}{l}\text { * Ateşten } \\
\text { Gomlek } \\
\text { * Kubbede Ka- } \\
\text { lan Hoş Sada } \\
\text { Halide Edib } \\
\text { Adıvar }\end{array}$ \\
\hline $\begin{array}{l}12 . \\
\text { SINIF }\end{array}$ & - & - & - & - & - \\
\hline
\end{tabular}

Tablo 7 incelendiğinde, dört y1llık orta öğretim süreci boyunca bir lise öğrencisinin edebiyat dersi kapsamında Halide Edib Adıvar, Sabiha Sertel, Şukufe Nihal Başar ve Leylâ Hanım olmak üzere dört kadın yazar/şair ile karşılaştığı görülmektedir. Öğrencilerin edebiyat eğitimi sürecinin temelini oluşturan metin okuma ve inceleme bölümünde ise dört yıl içerisinde sadece bu yazarlardan sadece Halide Edib Adıvar ve onun bir metni ile çalıştıkları dikkat çekmektedir. Türk edebiyatı ders kitaplarında diğer kadın yazar/şairlere örnek bir cümle, bir paragraf, bir dörtlük ve bir beyit boyutunda yer verilmiş olup bu metinler inceleme bölümünde ayrıntılı olarak incelenmemiş, etkinlik ya da değerlendirme sorusu olarak değerlendirilmiştir. Bu durum, lisede öğrenim gören öğrencilerin az sayıda kadın yazar/şair ve metinleri ile karşılaştıklarını göstermektedir.

\section{Sonuç ve Öneriler}

Çalışma kapsamında incelen antolojiler, ders kitapları, 100 temel eser listeleri, edebiyat ödülleri, ders içerikleri ve öğretmen adayı görüşleri göstermektedir ki; ders kitapları, ders içerikleri ve antolojilerde az sayıda kadın yazar ve şairlere yer verilmektedir ve öğretmen adaylarının kadın 
yazar ve şairlere ilişkin farkındalık düzeyi düşüktür. Öğretmen adaylarının kadın yazar ve şairlere ilişkin farkındalık düzeylerinin düşük olmasının nedenleri; 100 temel eser listeleri, edebiyat tarihleri, öğretim programları, antolojiler, önerilen yapıtlar ve ders kitaplarında kadın yazar ve şairlere yeterince yer verilmemesi olarak görülmektedir. Kadın yazar ve şairler yeterince tanıtılmamakta ve dolayısıyla tanınmamaktadırlar.

Kadın yazar ve şairlerin edebiyat eğitimi sürecinde ne düzeyde yer aldıklarını irdeleyerek Türk dili ve edebiyatı öğretmen adaylarının kadın yazarlara ilişkin farkındalıklarını belirlemeyi amaçlayan çalışma kapsamında ulaşılan sonuçlar şu şekildedir:

- Türk dili ve edebiyatı öğretmen adaylarının Cumhuriyet öncesi döneme ilişkin 78 erkek yazar/şair adı söylenirken 1 kadın yazar adı belirtmesi Cumhuriyet öncesi kadın yazarlara ilişkin farkındalıklarının düşük olduğunu göstermektedir.

- Türk dili ve edebiyatı öğretmen adaylarının okumaktan hoşlandığg erkek yazar say1sının (112) kadın yazar sayısına (15) oranla oldukça yüksek olması, kadın yazarlara ilişkin yeterli düzeyde metin okumadıklarını göstermektedir.

- Orta öğretim Türk edebiyatı ders kitaplarında dört kadın yazar/şairin metinlerinden (Halide Edib Adıvar, Sabiha Sertel, Şükûfe Nihal Başar ve Leylâ Hanım) örnek olmas1 ancak sadece Halide Edib Adıvar'ın metninin inceleme çalışmasında kullanılması, ders kitaplarında kadın yazar ve şairlere yok denecek kadar az yer verildiğini göstermektedir. Bu durum, lise öğrencilerinin kadın yazar/şair metinleri ile karşılaşamamalarını ve onları yeterince tanımamalarına neden olmaktadır.

- Türk Dili ve Edebiyatı Öğretmenliği lisans programı ders içeriklerinde oldukça az sayıda Cumhuriyet dönemi öncesi kadın yazar ve şaire (Halide Edib Adıvar, Zeynep Hanım, Mihri Hanım, Fatma Aliye) yer verildiği belirlenmiştir. Bu durumun, öğretmen adaylarının kadın yazar/şairlere ilişkin farkındalıklarını düşürdüğü düşünülmektedir.

- Öğrencilerin öğrenim sürecinde işledikleri yazarları sevdikleri yazarlar arasında gösterdikleri dikkat çekmektedir. Bu durum, öğrenim sürecine dahil edilen her kadın yazar/şair ile öğretmen adaylarının kadın yazar/şairlere ilişkin farkındalığının geliştirilebileceğini göstermektedir.

Çalışma sonunda incelen edebiyat tarihleri, antolojiler, ders kitapları, 100 temel eser listeleri, ödül yarışmaları, ders içerikleri ve öğretmen adayı görüşleri göstermektedir ki kadın yazar ve şairlere ilişkin farkındalık oldukça düşüktür. Öğretmen adaylarının kadın yazar/şairlere ilişkin farkındalığı, gelecek nesillerin de kadın yazar ve şairlere ilişkin farkındalığını doğrudan etkileyecektir. Bu nedenle, özellikle öğretmen adaylarının bu konudaki farkındalığını geliştirecek çalışmalara yer verilmesi gerektiği düşünülmektedir. Söz konusu sonuçlar doğrultusunda kadın yazar/şairler ve kadın yazınına ilişkin farkındalığı geliştirmek amacıyla aşağıdaki önerilerde bulunulabilir:

- Türk edebiyatı ders kitaplarında kadın yazar/şairlere ait metin sayısı arttırılarak öğrencilerin kadın yazar/şairler ile kadın yazınına ilişkin farkındalığı arttırılmalıdır.

- Türk dili ve edebiyatı lisans programlarının ders içerikleri Cumhuriyet öncesi ve sonrası kadın yazar/şairler ile kadın yazını açısından geliştirilmelidir. 
- $\quad$ Akademik çalışmalar yapan kadın araştırmacıların üniversitelerde kadın yazar ve şairlere ilişkin çalışmalar yapmalı ve onları genç nesillere tanıtmalıdır.

Herbert Read'e göre "Sanat eğitiminden amaç, daha çok 'iyi sanat eseri' yaratılması değil, daha iyi insanlar ve daha iyi toplumlar yaratılmasıdır" (San 1979, s.11). Bir güzel sanat eğitimi alanı olan edebiyat eğitiminin de amacı yazarlar yetiştirmek değil; düşünen, düşündüklerini ifade eden ve üreten, yaratıcı bireyler yetiştirmektir (Alpaslan, 2000). Ancak daha iyi insanlar ve toplumlar oluşturulurken sanata ve eğitime çok yönlü bakılması gerekmektedir ki kültürel ve toplumsal gelişme sağlıklı bir şekilde ilerleyebilsin. Mustafa Kemal'in 30 Mart 1923 tarihli Vakit gazetesinde belirttiği gibi "İnsan topluluğu kadın ve erkek denilen iki cins insandan oluşur. Kabil midir ki bu kütlenin bir parçasın ilerletelim, ötekini ihmal edelim de kütlenin bütünü ilerleyebilsin? Mümkün müdür ki bir cismin yarısı topră̆a bă̆lı kaldıkça, diğer yarısı göklere yükselebilsin?” Bu nedenle edebiyat eğitiminin sağlıklı gelişebilmesi için kadın yazar/şairlerin edebiyat tarihlerinde, antolojilerde ve özellikle ders kitaplarında erkek yazar ve şairlerle birlikte, eş düzeyde ele alınması ve aktarılması gerektiği düşünülmektedir.

\section{Kaynakça}

Alkaç, N. (201?). Edebiyyât-ı kadîmenin tâife-i nisvâsı/Osmanlı kadın şair(e)leri. Erciyes Aylık Fikir ve Sanat Dergisi, 30-33.

Alparslan, G., G. (2000). Derslikten günlük yaşama edebiyat eğitimi. Türkbilig, 185-202.

Aydıngör, F. (2006). Tanzimat döneminde (1839-1876) kadın yaşamında modernleşme. Yayımlanmamış yüksek lisans tezi, Anadolu Üniversitesi Sosyal Bilimler Enstitüsü, Eskişehir.

Büyüköztürk, Ş., Kılıç Çakmak, E., Akgün, Ö.E., Karadeniz, Ş. ve Demirel, F. (2010). Bilimsel araştırma yöntemleri. Ankara: PegemA Yayınları.

Bekiroğlu, N. (1999). Osmanlı'da kadın şairler, Osmanlı Ansiklopedisi. Yeni Türkiye Yayınları. (Ed.: Güler Eren), C. 9, 802-812.

www.nazanbekiroglu.org/2000/01/02/osmanlida-kadin-sairler/ - (Erişim Tarihi: 27.10.2013, 14:50)

Dündar, C. (2005). Neden kadın şair yok?, Milliyet Gazetesi (08.03.2005).

(http://www.milliyet.com.tr/2005/03/08/yazar/dundar.html) (Erişim Tarihi: 27.10.2013, 14:50)

Çakır, S. (1996). Türkiye'de kadın hareketinin dünü ve bugünü, Sivil Toplum Örgütleri Gözüyle Türkiye'de Kadının Eğitimi Sempozyumu (25 Aralı 1996), Türk Kütüphaneciler Derneği, Ankara, 100-122.

Çakır, S. (2011), Osmanlı kadın hareketi, İstanbul: Metis Yayınları.

Çakmak, B. (2011). Tanzimat'tan Cumhuriyet'e uzanan çizgide Osmanlı'da kadın hareketleri, dönemin tiyatrosunda kadının temsili ve kadın sorunu. Tiyatro Eleştirmenliği ve Dramaturji Bölüm Dergisi, S.18., s.44-79.

http://www.journals.istanbul.edu.tr/iutiyatro/article/view/1023020039

Doğanay, E. (1999). Kadın halk ozanları, Ozanca Yayınları: Berlin.

Doğan, N. (1994), Ders kitapları ve sosyalleşme (1876-1918). İstanbul: Bağlam Yayınları.

Dökmen, Y., Z. (2012). Toplumsal cinsiyet sosyal psikolojik açıklamalar. Remzi Kitabevi: İstanbul.

DKİH Projesi, (2009). Ders kitapları insan haklart ihlalleriyle dolu.

http://bianet.org/bianet/siyaset/112236-ders-kitaplari-insan-haklari-ihlalleriyle-dolu

Fuat, M. (2004). Çağdaş Türk şiiri. İstanbul: Adam Yayınevi.

Helvacıoğlu, F. (1996). Ders kitaplarında cinsiyetçilik 1928-1995. Kaynak Yayınları.

İspirli, S., A. (2007), Osmanlı kadınının şiiri, Turkish Studies, İnternational Periodical Fort he Languages, 
Literature and History of Turkish or Turkic, Volume 2/4, 446-454.

Karataş, E. (2009). Türkiye'de kadın hareketleri ve edebiyatımızda kadın sesleri. Turkish Studies International Periodical For the Languages, Literature and History of Turkish or Turkic Volume 4/8 Fall 2009, 16521674.

Komisyon (2012). Türk edebiyatı 9. sınıf ders kitabı. Ankara: Milli Eğitim Bakanlığı Yayınları 5008.

Komisyon (2012). Türk edebiyatı 10. sınıf ders kitabl. Ankara: Milli Eğitim Bakanlı̆̆ı Yayınları 5009.

Komisyon (2012). Türk edebiyatı 11. sınıf ders kitabı. Ankara: Milli Eğitim Bakanlığı Yayınları 5719.

Komisyon (2012). Türk edebiyatı 12. sınıf ders kitabl. Ankara: Milli Eğitim Bakanlığı Yayınları 4505.

Konyar, B. (2011). 20. yy.ın ilk çeyreğinde İstanbul'da kadın hareketleri, Kasım 2011. s.1-7.

http://akademik.maltepe.edu.tr/bkonyar/kadinhareketleri-konyar.pdf.

Kuşcan Akşit, Ö. (?). Antik çağdan günümüze kadının öyküsü. Ankara: Mattekmatbaa.

Önertoy, O. (1998). Cumhuriyet döneminde roman. Çağdaş Türk Edebiyatı içinde (s.115-135). Eskişehir: Açıköğretim Fakültesi Yayınları.

Pala, İ. (2008). Âşina güzeller. İstanbul: Kapı Yayınları.

San, İ. (1979), Sanatsal yaratma, çocukta yaratıcılık. Ankara: Türkiye İş Bankası Yay.

Tekeli, Ş. (2014). Akademyaların Cinsiyetçiliği Üzerine.

http://kasaum.ankara.edu.tr/files/2014/11/SirinTekeli_konusmasi6.pdf

Yılmaz, A. (2012). Geçmişten günümüze kadın şairlerin konumuna genel bir bakış. 21. Yüzyllda Eğitim ve Toplum. C.1., S.2, Yaz 2012, 46-63.

Wellek, R. ve Warren, A. (2005). Edebiyat teorisi. İstanbul: Dergah Yayınları.

Zeybekoğlu, Ö. (2013). Toplumsal cinsiyet bağlamında erkeklik olgusu. Ankara: Eğiten Kitap.

Vakit Gazetesi (30 Mart 1923) Atatürk'ün kadınlar ile ilgili konuşması. 